
Acta Universitatis Nicolai Copernici • Pedagogika XXXI/2015

Nauki Humanistyczno-Społeczne • Zeszyt 426

DOI: http://dx.doi.org/10.12775/AUNC_PED.2015.001

Witold Chmielewski

Instytut Nauk Pedagogicznych

Uniwersytet Jana Kochanowskiego

\title{
Obraz nauczyciela PRL W ŚWIETLE WEASNYCH WSPOMNIEŃ
}

\section{UWAGI WSTĘPNE}

\begin{abstract}
biektywne sformułowanie obrazu nauczyciela PRL jest potrzebne i uzasadnione rolą, jaką odegrał on w wychowaniu i ukształtowaniu pokolenia Polaków, które żyło i pracowało w czasach ograniczonej wolności, brało udział w transformacji ustrojowej oraz aktywnie uczestniczyło w głębokich przeobrażeniach mających miejsce w kraju w ostatnim dwudziestopięcioleciu. Przez cały ten czas nauczyciele starali się sumiennie realizować zadania dydaktyczno-wychowawcze w niełatwych warunkach indoktrynacji ideologicznej, zmian ustrojowych i kilkakrotnych reform w systemie edukacji. W tym okresie rozwijało się szkolnictwo wszystkich typów, powstawały nowe placówki oświatowo-wychowawcze, kształcono, zwłaszcza na poziomie średnim, wielu nauczycieli i wychowawców. Równolegle z tymi pozytywnymi zjawiskami związanymi z rozwojem ilościowym szkolnictwa występowała, począwszy od końca lat 40. do upadku PRL, głęboka indoktrynacja nauczycieli i uczniów poprzez upowszechnianie odpowiednich wzorców i treści nauczania oraz wychowania. Dużą rolę $\mathrm{w}$ oddziaływaniu ideologiczno-politycznym na szkołę odgrywa-
\end{abstract}


ło również stosowanie określonych środków administracyjnych w zakresie egzekwowania realizacji procesu dydaktyczno-wychowawczego, zalecanej przez władzę interpretacji otaczającej rzeczywistości i ograniczania swobody wypowiedzi, wolnego przepływu idei, myśli i informacji. W realizacji tak rozumianej polityki edukacyjnej w PRL szczególne miejsce przypadało nauczycielom ${ }^{1}$. Z tego też względu praca pedagogiczna stanowiła przedmiot zainteresowania władz oświatowych, administracyjnych i partyjnych wszystkich szczebli. Nauczyciele jako grupa społeczna mieli stać się istotnym elementem realizacji założeń polityki oświatowej prowadzonej przez partię komunistyczną. Jednak mimo odgórnych nacisków, ustawicznych dyrektyw i zarządzeń, nauczyciele w swej zdecydowanej większości nie ulegali tym wpływom i starali się wykonywać zadania wychowawcze najlepiej jak potrafili, zgodnie z uniwersalnym systemem wartości. Panuje przekonanie, że taka postawa cechowała większość polskich nauczycieli.

Idea poznania miejsca i roli nauczyciela w PRL z perspektywy kilkudziesięciu lat, a przede wszystkim przekazania doświadczeń zdobytych w pracy pedagogicznej młodemu pokoleniu adeptów tego zawodu, pojawiła się w kręgu osób skupionych wokół redakcji „Przeglądu Historyczno-Oświatowego" i Polskiego Towarzystwa Pedagogicznego. Zagadnienie to postanowiono przedstawić jednak nie w świetle zachowanych dokumentów archiwalnych, wytworzonych w ośrodkach władzy, a więc uchwał, zarządzeń, decyzji, pism urzędowych i sprawozdań, ale na podstawie relacji nauczycieli i uczniów, które przybierały charakter opracowań pamiętnikarskich, będących rezultatem badań zrealizowanych przy pomocy kwestionariusza ankiety². W ten sposób

1 R. Grzybowski, Polityczne priorytety i elementy codzienności socjalistycznej szkoły. Wybór studiów poświęconych dziedzictwu edukacyjnemu PRL-u, Toruń 2013, s. 179-194.

2 Szerokie badania w oparciu o relacje nauczycieli prowadzi Wanda Dróżka, por.: W. Drużka, Pokolenia nauczycieli, Kielce 1993; taż, Młode pokolenie nauczycieli. Studium autobiografii młodych nauczycieli polskich lat dziewięćdziesiątych, Kielce 1997; taż, Nauczyciel autobiografia pokolenia. Studium pedeutologiczne i pamiętnikoznawcze, Kielce 2002. 
ukazały się cztery pozycje wydawnicze z zakresu literatury pamiętnikarskiej ${ }^{3}$.

Ostatnia z wydanych na ten temat publikacji różni się od poprzednich metodologią przeprowadzonych badań i czasem, którego dotyczy. O ile pierwsze trzy książki obejmują wspomnienia nauczycieli i uczniów tylko z lat 1944-1956, o tyle czwarta zawiera rezultaty badań przeprowadzonych w oparciu o kwestionariusz ankiety wśród nauczycieli pracujących w różnych okresach dziejów PRL, a także w okresie transformacji ustrojowej po 1989 roku. Inicjatywę badawczą zrealizowano, zamieszczając imieniem Zarządu Głównego Polskiego Towarzystwa Pedagogicznego na łamach „Głosu Nauczycielskiego” w dniu 29 marca 2000 roku kwestionariusz ankiety pt. Pożegnanie ze szkołą. Spojrzenie wstecz nauczyciela emeryta i jego doświadczenia pedagogiczne. We wstępie do kwestionariusza napisano: „Koleżanko, Kolego! Świadomi wagi i znaczenia ciągłości pokoleniowej w wychowaniu obywateli naszego państwa, zwracamy się do Was z prośbą o podzielenie się Waszym doświadczeniem, refleksjami i opiniami, ukształtowanymi w długoletniej, zaszczytnej pracy dydaktyczno-wychowawczej. Dołożymy starań, aby Wasze wypowiedzi uczynić kanwą publikacji, której celem byłoby przekazanie bogactwa doświadczeń starszego pokolenia naszych pedagogów czynnym nauczycielom i adeptom pedagogiki. [...] bardzo prosimy, abyście pisali prawdę i tylko prawdę. Każdy sąd i każdą opinię starajcie się uzasadnić i poprzeć przykładami"4.

Kwestionariusz ankiety zawierał, nie licząc prośby o podanie podstawowych danych osobowych, siedem pytań dotyczących:

- przebiegu pracy dydaktycznej w szkołach (warunki pracy, atmosfera w szkole, wyniki nauczania, postawa uczniów i ich szczególnie naganne zachowanie);

3 Na przełomie. Wspomnienia nauczycieli i uczniów z lat 1944-1956, wybór i oprac. E. C. Król, M. Walczak, Warszawa 1994; Na przełomie, cz. II-III, Antologia relacji i uczniów z lat 1944-1956, wybór i oprac. S. Mauersberg, M. Walczak, Warszawa 1996; Pożegnanie ze szkołą. Spojrzenie wstecz nauczyciela emeryta, wybór i oprac. W. Chmielewski, S. Mauersberg, M. Walczak, Piotrków Trybunalski 2012.

4 Pożegnanie ze szkoła. Spojrzenie wstecz nauczyciela emeryta i jego doświadczenia pedagogiczne, „Głos Nauczycielski” 2000, nr 13, s. 10. 
- satysfakcji z pracy dydaktycznej i wychowawczej;

- największych osiągnięć dydaktycznych i wychowawczych;

- najbardziej interesujących wydarzeń pedagogicznych w wykonywanej pracy nauczycielskiej;

- błędów i porażek, których nie udało się uniknąć w pracy z młodzieżą;

- doświadczeń, które należało przekazać następcom w zawodzie nauczycielskim (rozpoczynającym pracę, podnoszącym swoje kwalifikacje, organizującym zajęcia pozalekcyjne i pozaszkolne, kierującym placówką oświatowo-wychowawczą, sprawującym nadzór pedagogiczny, działającym w ZNP lub innych organizacjach oświatowych);

- innych spraw związanych ze szkołą, np. oświatą pozaszkolną, współpracą z rodzicami i środowiskiem, represjami politycznymi i policyjnymi ${ }^{5}$.

Kwestionariusz ankiety wypełniło stu nauczycieli. Część spośród nich szeroko i dokładnie odpowiedziała na postawione pytania. Inni nieco krócej i mniej wnikliwie. Niektóre nadesłane wypowiedzi nie nadawały się do opublikowania. Zawierały bowiem sformułowania dotyczące długo skrywanej niechęci do swoich bezpośrednich, lokalnych przeciwników w szkole lub w środowisku. Kilkanaście kwestionariuszy było wypełnionych niestarannie, zawierało nieścisłości i nie wnosiło żadnej zasługującej na uwagę myśli. Ostatecznie, po wnikliwej analizie, wytypowano do druku treści zawarte w 66 kwestionariuszach. Ich autorami było 51 kobiet i 15 mężczyzn. Kilka odpowiedzi obejmowało 20 i więcej stron. Respondenci byli emerytami w różnym wieku. Najstarsi rozpoczęli pracę nauczycielską jeszcze przed wojną, najmłodsi przeszli na emeryturę pod koniec lat 90. Największą grupę stanowił osoby czynne zawodowo od lat 50. do 80. ubiegłego stulecia. Współtworzyli oni po wojnie polskie szkolnictwo wszystkich typów 6 .

5 Tamże.

6 W. Chmielewski, Informacje o autorach wspomnień, w: Pożegnanie ze szkoła. Spojrzenie wstecz nauczyciela emeryta, wybór i oprac. W. Chmielewski, S. Mauersberg, M. Walczak, Piotrków Trybunalski 2012, s. 217-223. 
Wszechstronny, niekiedy dosyć szczegółowy wachlarz zagadnień podejmowanych $\mathrm{w}$ kwestionariuszu ankiety, zachęcał respondentów do wnikliwych i interesujących wypowiedzi oraz refleksji. W ten sposób zarysował się rzeczywisty obraz środowiska nauczycielskiego okresu PRL, widziany oczyma tych, którzy bezpośrednio, głęboko w nim tkwili: nauczycieli przedszkoli, szkół podstawowych, średnich ogólnokształcących, zawodowych, metodyków nauczania niektórych przedmiotów i - w pojedynczych przypadkach - wykładowców szkół wyższych oraz przedstawicieli terenowej administracji szkolnej. Z relacji badanych nauczycieli wynika, że wykonywaną pracę traktowali niezwykle obowiązkowo, z pasją. Jedna ze starszych wiekiem nauczycielek pisała: „Zawód nauczycielski był przeze mnie obrany z zamiłowania [...]. Nie musiałam nigdy uciekać się do używania groźby czy przymusu. Wspólnie z rodzicami dzieci tworzyliśmy wspaniałą rodzinę. Satysfakcją moją jest fakt, że po wielu latach moi uczniowie darzą mnie miłością i szacunkiem"7.

\section{NIEKTÓRE ASPEKTY WARUNKÓW REALIZACJI PRACY DYDAKTYCZNO-WYCHOWAWCZEJ}

Analizując problem przebiegu pracy dydaktyczno-wychowawczej, należy zauważyć, że niemal wszyscy respondenci wskazywali na trudne warunki lokalowe polskich szkół, zwłaszcza w okresie powojennym. W wyniku drugiej wojny światowej wiele budynków szkolnych było zdewastowanych. „W klasach było zimno, okna i drzwi nieszczelne, z zaciekającym dachem, bez wody, ogrzewanie piecowe ${ }^{8}$. W jednej ze szkół w Poznaniu zawalił się pewnej nocy dach"9. Ciasnota izb lekcyjnych, wynajmowanie pomieszczeń dla potrzeb dydaktycznych w domach prywatnych, nauczanie w klasach łączonych było zjawiskiem niezupełnie odosobnionym. Niewielkie izby lekcyjne ogrzewane kuchnią z fajerkami lub piecykiem „cygankiem” spotkać można było nawet

\footnotetext{
7 Pożegnanie ze szkoła. Spojrzenie wstecz nauczyciela emeryta, s. 95.

8 Tamże, s. 63.

9 Tamże, s. 41.
} 
w dużych osadach czy też miasteczkach. Warunki lokalowe wywarły wpływ na nauczanie i wychowanie w wielu szkołach, ale wcale nie przesądzały o jego niskim poziomie ${ }^{10}$. Wręcz odwrotnie, chęć do pracy nauczycieli była tak duża, że z nawiązką starali się oni pokonać napotykane trudności. „Nie było podręczników, najprostszych pomocy naukowych. Zapał jednak nauczycieli i dzieci był wielki. Z rozrzewnieniem wspominam te pierwsze lata mojej pracy, choć wynagrodzenie było symboliczne"11.

Jak wynika z relacji badanych nauczycieli, w chwili podejmowania pracy w szkołach mieli oni zróżnicowane wykształcenie. Byli wśród nich absolwenci seminariów nauczycielskich, liceów pedagogicznych, przedwojennych wyższych kursów nauczycielskich. Wielu rozpoczynało pracę jako nauczyciele niewykwalifikowani. Zawsze jednak istniała możliwość podnoszenia kwalifikacji w komisjach rejonowych czy innych formach edukacji. W późniejszych latach nauczyciele kończyli studia nauczycielskie, studia zawodowe oraz wyższe szkoły pedagogiczne i uniwersytety. Szczególnie wiele pozytywnych wypowiedzi kierowano pod adresem liceów pedagogicznych. Absolwenci tych zakładów kształcenia nauczycieli podają, że nie tylko zdobywali wiedzę ogólnokształcącą, pedagogiczną i zakresu przedmiotów artystyczno-manualnych, ale także uczyli się umiejętności przydatnych w życiu codziennym, np.: posługiwania się sztućcami, zachowania się w miejscach publicznych, $w$ domu, szkole, pociągu, tramwaju itp. ${ }^{12}$

W nadesłanych wspomnieniach podkreślano, że osiąganie wyników dydaktycznych połączone było zazwyczaj z dużym wysiłkiem wychowawczym. Wyrażano przekonanie, że efekty pracy pedagogicznej w dużej mierze zależą od nauczyciela, jego postawy, osobowości, stosunku do uczniów, chęci zaangażowania się w pracę z podopiecznymi poza lekcjami, umiejętności nawiązywania kontaktów z otoczeniem, a zwłaszcza z rodzicami, wykonywania czynności i zadań, za które nie należy oczekiwać szczególnych gratyfikacji i zapłaty. Nie wszystko ma bowiem wymiar finansowy i da się przeliczyć na korzyści mate-

\footnotetext{
10 Tamże, s. 55, 63.

11 Tamże, s. 61.

12 Tamże, s. 46, 64, 198.
} 
rialne $^{13}$. Bardzo liczyła się satysfakcja z dokonań dydaktyczno-wychowawczych, którą - jak twierdziła większość badanych respondentów - udało się osiągnąć. Niektórzy nauczyciele przyznawali jednak, że ich starania nie zawsze przynosiły należyte rezultaty, a oni sami zaznawali goryczy porażki oraz niepowodzenia w pracy z uczniami. Przypadków takich jednak odnotowano niewiele. Jak słusznie konstatuje prof. Stanisław Mauersberg, „w ankiecie pytano o popełnione błędy i poniesione porażki w pracy dydaktyczno-wychowawczej. Odpowiedzi na to pytanie są przeważnie krótkie i zdawkowe. Okazuje się, że osławiona »samokrytyka«, tak często wymagana w Polsce Ludowej, nie wszystkich nauczyła krytycznej analizy własnych poczynań"14.

Część natomiast nauczycieli zabrała głos na temat stosunków międzyludzkich panujących w szkołach. Akcentowano solidarność nauczycielską. „Chyba na specjalne podkreślenie - informuje respondentka - zasługuje w tej mojej szkole współpraca koleżeńska i atmosfera wprost rodzinna w gronie nauczycielskim - fakt, który wysoko liczy się w pracy pedagogicznej i rzutuje na wyniki nauczania i wychowania. W szkole naszej obowiązywało hasło ,jeden za wszystkich, wszyscy za jednego"15. Dbałość o właściwe relacje w pracy eksponuje także inna emerytowana nauczycielka, pisząc: „Zwracano uwagę na atmosferę pracy, podkreślając doniosłe znaczenie relacji nauczyciel-uczeń, nauczyciel-dyrektor, nauczyciel-program nauczania, nauczyciel-wyniki nauczania i wychowania"16.

Pojawiały się też i opinie przeciwne. Przeważały jednak te o charakterze pozytywnym. Wielu spośród nauczycieli emerytów z pewnym rozrzewnieniem wspomina pierwsze lekcje, spotkania z uczniami, kontakty z gronem nauczycielskim. Po latach doświadczeni już pedagodzy szczególnie doceniają fakt opieki nad początkującym nauczycielem przez starszych przedstawicieli grona pedagogicznego,

13 Tamże, s. 47, 58.

14 S. Mauersberg, Wstęp, w: Pożegnanie ze szkoła. Spojrzenie wstecz nauczyciela emeryta, wybór i oprac. W. Chmielewski, S. Mauersberg, M. Walczak, Piotrków Trybunalski 2012, s. 12-13.

15 Pożegnanie ze szkołą. Spojrzenie wstecz nauczyciela emeryta, s. 18.

16 Tamże, s. 61. 
możliwości zatrudnienia, zwłaszcza w kontekście obserwowanej obecnie trudnej sytuacji absolwentów studiów o charakterze nauczycielskim (niekiedy własnych dzieci, które poszły w ślad rodziców i teraz są bezrobotnymi). Początkujący adept zawodu pedagogicznego otoczony był także troską kierownika szkoły, a czasami koła Związku Nauczycielstwa Polskiego (do którego w zasadzie przynależność była obligatoryjna) i komitetu rodzicielskiego. Pedagodzy podkreślają kulturotwórczą rolę małych szkół w wioskach odległych od dużych miast. Są zdecydowanie przeciwni ich likwidacji ze względu na brak nauczycieli, należyte, wyposażenie dydaktyczne i kwestie finansowe. Uważają, że placówki te stanowią ważne ośrodki umacniania więzi środowiskowej, a ich funkcje społeczne są dużo istotniejsze niż rachunek ekonomiczny ${ }^{17}$. Należy zaznaczyć, że problem likwidacji małych szkół, obecnie podnoszony przez samorządy wyłącznie w kontekście uwarunkowań finansowych, jest nadal aktualny ${ }^{18}$.

Świętem szkoły były konferencje ogniska ZNP na terenie gminy. Wygłaszano na nich referaty poświęcone ogólnej metodyce nauczania czy też referaty z zakresu poszczególnych przedmiotów. Dużym zainteresowaniem nauczycieli cieszyły się lekcje pokazowe. Po zakończeniu części oficjalnej uczestniczono we wspólnym, uroczystym obiedzie, podczas którego trwała nadal wymiana doświadczeń, przeradzająca się często w rozmowy o charakterze towarzyskim, umożliwiające wzajemne poznanie się i zaprzyjaźnienie. Niekiedy spotkania takie kończyły się tańcami. Podobne konferencje organizowano na szczeblu powiatowym przed rozpoczęciem roku szkolnego (w czasach stalinowskich nazywano je rejonowymi). Były one z reguły dwuczęściowe: o charakterze ogólnym - dla wszystkich i przedmiotowe dla poszczególnych grup nauczycieli. Ponadto odbywały się również śródroczne konferencje metodyczne dla nauczycieli prawie wszystkich przedmiotów, zwoływane przez nauczycieli-metodyków, które

17 Tamże, s. 55, 57.

18 Petycja uczestników manifestacji do Joanny Kluzik-Rostkowskiej, ministra edukacji narodowej. Wzywamy do podjęcia dialogu, „Głos Nauczycielski” 2015, nr 17, s. 5. 
wywierały istotny wpływ na poziom nauczania ${ }^{19}$. Zwraca uwagę fakt, że respondenci dobrze wspominają te oraz inne formy uzupełniania i doskonalenia wiedzy pedagogicznej, nie odczuwają dominującego nasycenia ich treściami ideologicznymi i politycznymi, wynikającymi z założeń i zaleceń odgórnych władz ${ }^{20}$. Można więc wysnuć wniosek, że dyspozycje te nie docierały bądź były świadomie lekceważone i nierealizowane przez zwykłych nauczycieli, a więc przez tych, do których były przede wszystkim adresowane.

Pozytywnie respondenci wypowiadali się na temat współpracy z komitetami rodzicielskimi. $\mathrm{Z}$ ich relacji wynika, że kontakty te bardzo korzystnie wpływały zarówno na działalność każdej szkoły, jak i na pracę klas oraz poszczególnych nauczycieli. Współpraca z rodzicami przynosiła nauczycielom dużo satysfakcji. Rodzice chętnie uczestniczyli w pracach na rzecz szkoły. Formy aktywności i pomocy rodziców były bardzo różnorodne i zawsze miały na celu dobro szkoły i nauczyciela. Niektóre z nich odeszły już bezpowrotnie w przeszłość, jak np. dostarczanie furmanek, czyli tzw. podwód, celem zawiezienia nauczycieli na konferencję ogniska ZNP lub na inne zebranie. Dosyć powszechny był udział rodziców w remontach, modernizacji i budowie nowych szkół oraz skutecznym wspieraniu wszelkich inicjatyw o charakterze gospodarczym. Owocem tej współpracy były nie tylko widoczne rezultaty natury materialnej, ale także rozwijane i umacniane więzi towarzyskie pomiędzy nauczycielami a środowiskiem. Niejako uzupełnieniem współpracy szkoły z otoczeniem w latach 50. i 60., zwłaszcza na wsi, było zwalczanie analfabetyzmu. Nauczyciel cieszył się dużym autorytetem. Panowało przekonanie, że po księdzu był on pierwsza osobą we $\mathrm{wsi}^{21}$.

19 Pożegnanie ze szkołą. Spojrzenie wstecz nauczyciela emeryta, s. 56, 63.

20 E. Kahl, Instytucjonalne doskonalenie nauczycieli w PRL (1956-1989). Ideologia - polityka - praktyka, Zielona Góra 2012, s. 27, 32, 57; F. Mielczarek, Ideologiczno-polityczna indoktrynacja nauczycieli $w$ Polsce $w$ latach 1945-1956, Opole 1997, s. 19, 31-32.

21 Pożegnanie ze szkoła. Spojrzenie wstecz nauczyciela emeryta, s. 193-208. 


\section{Represje POLITYCZne I POLICYJNe}

W literaturze naukowej, dotyczącej sytuacji społeczno-politycznej w oświacie w okresie PRL, można spotkać wiele opracowań na temat represji politycznych i indoktrynacji nauczycieli oraz uczniów. Rozpatrują one to zagadnienie w różnych aspektach, zawsze jednak słusznie mają wymiar krytyczny ${ }^{22}$. Również w charakteryzowanych w niniejszym artykule wybranych rezultatach badań przedstawiających obraz nauczyciela w PRL ukazane są wspomnienia na temat. Należy jednak zauważyć, że w stosunku do ogólnej liczby wszystkich wypowiedzi liczba przytoczonych zdarzeń podejmujących tę problematykę jest stosunkowo niewielka. Należy to tłumaczyć tym, że kwestionariusz ankiety rozprowadzono wśród nauczycieli emerytów już ponad dziesięć lat po upadku PRL. Część autorów wypowiedzi przeszła na emeryturę znacznie wcześniej i niektóre tego typu fakty z ich życia mogły ulec zatarciu. Trzeba też wziąć pod uwagę i to, że starsze osoby, pisząc po latach wspomnienia, z reguły z dużą nostalgią przywołują okres swojej młodości i nie chcą nawiązywać do przykrych faktów z przeszłości. Niektóre osoby, ustosunkowując się do odpowiedniego pytania $\mathrm{w}$ analizowanym kwestionariuszu ankiety piszą, że nie były represjonowane politycznie i policyjnie. Spora część respondentów nie zajmowała w tej sprawie stanowiska. Najczęściej pojawiała się kwestia stosunku nauczycieli do spraw o charakterze religijnym. Jedna z nauczycielek przyznaje, że dobrze wspomina czasy PRL. Jako członek

22 F. Mielczarek, Ideologiczno-polityczna...; K. Kosiński, O nową mentalność. Życie rodzinne w szkołach 1945-1956, Warszawa 2000, s. 65-79, 144-158; J. Wojdon, Propaganda polityczna w podręcznikach dla szkót podstawowych Polski Ludowej (1944-1989), Toruń 2001; T. Kukułowicz, Represje wobec nauczycieli w latach 1947-1956 w świetle wypowiedzi, w: Oblicze ideologiczne szkoty polskiej w latach 1944-1995, pod red. ks. E. Walewandera, Lublin 2002, s. 205-210; S. Mauersberg, Indoktrynacja młodzieży szkolnej. Programy, podręczniki, lektura, pod red. ks. E. Walewandera, Lublin 2002, 211-235; S. Mauersberg E. J. Kryńska, S. W. Mauersberg, Indoktrynacja młodzieży szkolnej w Polsce w latach 1945-1956, Białystok 2003; W. Chmielewski, Kształcenie nauczycieli w okresie ideologizacji szkolnictwa (1944-1956), Warszawa 2006; E. Kahl, Instytucjonalne... 
partii komunistycznej nie obnosiła się ze swoimi poglądami religijnymi, ale też nie tłumaczyła się przed nikim z powodu chodzenia do kościoła. Dzięki partii otrzymała natomiast mieszkanie. Były kierownik i dyrektor szkoły z ponad dwudziestoletnim stażem informuje, że nie zaznał większego nacisku politycznego ani policyjnego, chociaż wiedział o takich przypadkach, które dotyczyły innych osób. W miejscowości, w której pracował, ochrzcił i posłał do pierwszej komunii św. czworo dzieci. Każde z nich systematycznie uczęszczało na lekcje religii ${ }^{23}$. Kilkoro jednak respondentów podaje, że odczuwało bezpośrednio w stosunku do swojej osoby określone naciski. Oto przykłady:

„W ramach represji politycznych [pisze nauczycielka o czasach stalinowskich] posądzono mnie o współpracę z księdzem [Ignacym] Ziembickim, gdyż ułożyłam mu plan religii bez »okienek«, utrudniających pracę dydaktyczną. Ksiądz Ziembicki zbudował w czasie mojej kadencji kierowniczki szkoły kościół w Małęczynie, a dotychczasową kaplicę przeznaczono na szkołę. Pomagaliśmy księdzu jako pedagodzy. Zostałam za to wezwana do Wydziału Oświaty [...] zwolniono mnie z funkcji dyrektora szkoły”24. Inna nauczycielka wspomina: „Represje polityczne nie minęły mnie. Miałam brata księdza - doktora prawa kanonicznego. Byliśmy i jesteśmy rodziną o dość mocnych postawach religijnych. Córki nosiły łańcuszki z krzyżykami na szyi, chodziły do kościoła, przystępowały do Pierwszej Komunii Świętej. Byłam wzywana do komitetu partii »na dywanik«, na rozmowy. Skreślano mnie z listy nagród, pouczano, upominano, ale wszystko na nic"25. Jeszcze inny nauczyciel informuje o wcale nie odosobnionym ruchu służbowym w ramach tzw. czystek kadrowych: „[...] zostałem karnie przeniesiony do Szkoły Podstawowej nr 6 [w Gnieźnie] (przyczyna - odmowa zdjęcia obrazu Matki Bożej wiszącego nad wejściem do klasy)"26.

Stawianie nauczycielom wymagań edukacji uczniów w duchu świeckim, rozliczanie przez władze, zwalczanie wychowania religijnego, zalecanie kształtowania tzw. naukowego poglądu na świat, jednocześnie dą-

23 Pożegnanie ze szkołą. Spojrzenie wstecz nauczyciela emeryta, s. 203.

24 Tamże, s. 202.

25 Tamże, s. 208.

26 Tamże, s. 39. 
żenie pedagogów do wytrwania w wierze ojców i formowania u swoich uczniów prawidłowych postaw, rodziło wśród wielu z nich wewnętrzne rozterki. Z jednej strony pragnęli oni zachować w domu tradycję życia rodzinnego w duchu religii chrześcijańskiej, z drugiej zaś - aby móc wykonywać zawód, byli zmuszeni realizować narzucone urzędowo wychowanie ateistyczne. Taka sytuacja źle służyła szkole, uczniom i nauczycielowi.

Pojawiały się różnorodne formy wywierania presji na nauczycieli za brak jednoznacznej akceptacji istniejącej w PRL-u rzeczywistości. „Byłam karana [pisze jedna $\mathrm{z}$ emerytowanych nauczycielek] przez moje władze oświatowe za zbyt sztywny kręgosłup. Nie dostawałam nagród i wyróżnień, ponieważ byłam uważana za »krytykanta« polityki oświatowej (mimo że uczyłam o wyższości ustroju socjalistycznego nad kapitalistycznym, a dzieci ze szkoły podstawowej i liceum dawały mi przykłady, że się mylę. Np. nie kryłam, że moim zdaniem wprowadzenie do szkół gminnych przygotowania do reformy (10-latka) było bez sensu. Nie wykonywałam poleceń dyrektorów szkół, które uważałam za niesłuszne, np. wystawianie oceny na zlecenie dla dzieci prominentów"27.

Mąż jednej z autorek relacji, również nauczyciel, został przeniesiony z inicjatywy partyjnych władz gminy do sąsiedniej szkoły i musiał tam dojeżdżać rowerem. Powodem tej decyzji było stosowanie przez nauczyciela w pracy z harcerzami skautowskich metod wychowawczych ${ }^{28}$. Z kolei inna respondentka informuje, że była „prześladowana” przez sekretarza PZPR w gminie za sam fakt, że nie chciała należeć do tej partii ${ }^{29}$.

Jak już wcześniej wspomniano, na ogół grona nauczycielskie były solidarne, a atmosfera w szkołach, zwłaszcza mniejszych, była dobra, a nawet serdeczna. Nie wszędzie jednak było aż tak dobrze, szczególnie w niektórych szkołach średnich. „,Kabli« było w szkole sporo. Takie to były czasy... Byli to koledzy z pracy - mierni, bierni ale wierni, były to dzieci milicjantów, uczniowie, którzy »wpadli« w ubeckie łapy i pod groźbą wyrzucenia ze szkoły zmuszani byli do współpracy"30.

\footnotetext{
27 Tamże, s. 200-201.

28 Tamże, s. 55.

29 Tamże, s. 209.

30 Tamże, s. 180.
} 
Doświadczony i długoletni nauczyciel podaje przykład niechlubnych działań przewodniczącego ZMP w Liceum Pedagogicznym w Sulechowie, który naskarżył na niego, że na zajęciach w szkole, biwakach i wycieczkach upowszechniał gry skautowskie i harcerskie, a pomijał metody pracy pionierów radzieckich. Przedstawiciele ZMP uczestniczyli w posiedzeniach rad pedagogicznych. W tymże liceum powstała w 1949 roku nielegalna organizacja młodzieżowa pod nazwą Konspiracyjny Związek Patriotów Polskich, nawiązująca swoim programem do Zrzeszenia „Wolność i Niezawisłość". Związek stawiał sobie za cel walkę z bolszewizmem, przeciwstawianie się propagandzie komunistycznej, kolektywizacji wsi i innym działaniom nowej władzy. Inwigilacja bezpieki doprowadziła do aresztowania członków nielegalnej organizacji i wymierzenia im wysokich kar więzienia ${ }^{31}$.

Przykładów niegodzenia się uczniów z istniejąca rzeczywistością i dumy z polskości przytoczono znacznie więcej. Oto uczeń, wysłuchawszy omawiania przez nauczycielkę czytanki o życiu komsomolskiej młodzieży w Związku Radzieckim, gdy ta wychodziła już po zakończonej lekcji z klasy, odniósł się do jej wypowiedzi, mówiąc do kolegów: „oni nas wyprowadzą na banty". Należy tu nadmienić, że na zajęciach uczeń ten logicznie i pozytywnie analizował pracę sowieckiej organizacji młodzieżowej. Inny chłopiec, który dostał ocenę dostateczną z języka polskiego, a dobrą z języka rosyjskiego, prosił nauczycielkę, aby obniżyła mu stopień z tego nielubianego przedmiotu. Uznał bowiem, że było czymś wysoce niestosownym dla niego, jako powstańca warszawskiego, mieć lepszą ocenę z języka faktycznego okupanta niż z języka ojczystego. Jak wynika z relacji tej samej respondentki, rola nauczyciela, zwłaszcza przedmiotów humanistycznych, nie była łatwa. $Z$ jednej strony był on bowiem zobowiązany spełniać wymogi programowe, z drugiej zaś dążył do przekazywania uczniom tych treści nauczania, które zgodne były z jego przekonaniami i odczuciem ogółu Polaków. Świadczy o tym następująca adnotacja: „Tematyka programu języka polskiego w czasach stalinowskich stawiała nas, polonistów, w bardzo kłopotliwej sytuacji. Podręczniki języka polskiego obfitowały w materiały z tendencyjnej literatury sowieckiej. Lekcje na te tematy wymagały nie lada dyplomacji,

31 Tamże, s. 197-198. 
aby zachować twarz wobec uczniów i nie narazić się władzom nie tylko oświatowym, ale także partyjnym"32.

Na podstawie przytoczonych przykładów można powiedzieć, że ingerencja władzy i prezentowanej przez nią ideologii wyraziście i z reguły negatywnie wpływała na życie i pracę pedagogiczną nauczycieli. W całym okresie istnienia PRL-u, nauczyciele, chcąc wychowywać powierzonych ich pieczy uczniów w duchu podstawowych wartości, zmuszeni byli podporządkowywać się w różnym stopniu (w zależności od zajmowanego stanowiska, stosunków koleżeńskich panujących w szkole, środowiska) wytycznym o charakterze ideologicznym i politycznym. Nauczyciele na ogół dzielnie znosili tę sytuację i starali się tak postępować, aby być w porządku wobec uczniów, rodziców i samych siebie.

Presja ideologiczna i polityczna wywierana była także na uczniów. Czyniono to głównie poprzez realizację zindoktrynowanych programów nauczania i odpowiedniego systemu wychowania. Stosunek uczniów, zwłaszcza szkół średnich, do przekazywanych w tym duchu wiadomości był negatywny. Z tego też względu upowszechnianie treści opartych na tzw. pedagogice marksistowskiej przysparzało nauczycielom wielu trudności. Dotyczyło to zwłaszcza przedmiotów humanistycznych i przyrodniczych, na których należało pokazywać osiągnięcia rzekomo przodującej nauki radzieckiej i dokonań takich jej przedstawicieli, jak np. Iwan Miczurin i Trofim Łysenko ${ }^{33}$.

\section{PrzekazyWanie doświadczeń I UdZielanie Rad MLODSZYM POKOLENIOM NAUCZYCIELI}

Obraz nauczyciela wyłaniający się ze wspomnień określonych ramami kwestionariusza ankiety wydatnie poszerzają doświadczenia, przemyślenia i rady, które pragną przekazać swoim następcom zasłużeni nauczyciel emeryci, nadal całym sercem związani z głównymi problemami nurtującymi edukację młodego pokolenia. Podkreślają rolę zawodu nauczycielskiego dla kraju, przeżywają jego wzloty i niepowodzenia,

\footnotetext{
32 Tamże, s. 53.

33 Tamże, s. 197.
} 
ale zawsze doceniają jego znaczenie. Jedna z badanych osób zauważa: „Skąd pobrali się wszyscy profesorowie, inżynierowie itp. w kręgach rządowych i parlamentarnych? Przecież ktoś zaczynał ich edukację od prostego abecadła. Tym kimś był nauczyciel. Nie wolno im tego zapominać" ${ }^{34}$. Zatroskani o dobro ucznia, szkoły i poprawy sytuacji społecznej, materialnej oraz zawodowej, nauczyciele dzielą się we wspomnieniach swoimi refleksjami, wieloma wartościowymi spostrzeżeniami i praktycznymi uwagami. Motywem przewodnim wszystkich ich wypowiedzi, zawierających wiele cennych rad i wskazówek, jest stała troska o zachowanie autorytetu zawodu nauczyciela, dbanie nie tylko o jego godność, ale także o szacunek do ucznia, a przede wszystkim o wysoki poziom szkoły, służącej jak najlepiej swojej ojczyźnie. Zdaniem prof. Stanisława Mauersberga zaprezentowane na ten temat opinie wynikają z długoletniego doświadczenia pedagogicznego i stanowią „swoiste vademecum początkującego nauczyciela”, są prawdziwą, ciągle aktualną skarbnicą wiedzy o zawodzie nauczycielskim ${ }^{35}$. Rady nauczycieli emerytów przekazywane pracującym kolegom są przeznaczone dla dyrektorów szkół, nadzoru pedagogicznego, a także dla członków i działaczy Związku Nauczycielstwa Polskiego.

Szczególnie wiele życzliwych rad kierowano pod adresem młodych nauczycieli, zwłaszcza tych rozpoczynających pracę w szkole. Uprzedzano ich, że jeśli wybiorą ten zawód, nie będzie im łatwo zarówno ze względu na wielką odpowiedzialność przed społeczeństwem, jak i z uwagi na jego niski status materialny. Jedna z byłych nauczycielek pisze: „Każdy kandydat na nauczyciela powinien się zastanowić, czy idzie do tego zawodu z powołania, czy też z konieczności. Kto nie kocha dzieci tych grzecznych i tych trudnych, ten szybko przy pierwszych niepowodzeniach załamie się, zniechęci i może przepaść jako pedagog i nauczyciel. Jest to praca, zawód wymagający ogromnego opanowania, spokoju, cierpliwości i taktu [...]. Ciężka to praca, ale jak się osiągnie zamierzony cel, daje wiele satysfakcji" ${ }^{36}$. Kwestia bezwarunkowego kochania dzieci takimi, jakimi są, okazywanie im empatii

\footnotetext{
34 Tamże, s. 169.

35 S. Mauersberg, Wstęp..., s. 13.

36 Pożegnanie ze szkołą. Spojrzenie wstecz nauczyciela emeryta, s. 175.
} 
i zrozumienia jest zdaniem respondentów bardzo ważne i pojawia się wielokrotnie. Osoby, które przepracowały z dziećmi i młodzieżą kilkadziesiąt lat, uważają, że serdeczny stosunek do wychowanków stanowi podstawowy warunek dobrej pracy pedagogicznej. „Nie ma gotowych recept na to, by być dobrym nauczycielem. Uważam jednak, że w pracy trzeba kierować się sercem. Tylko to ma sens, to daje nam satysfakcję i radość"37.

Nauczyciel powinien odznaczać się optymizmem, kochać prawdę, piękno i dobro. Wszelkie jego troski i problemy o charakterze prywatnym, humory i nastroje muszą zniknąć z chwilą, gdy wejdzie do klasy i stanie przed uczniami. Powinien być punktualny, nie spóźniać się na zajęcia, jednocześnie mieć pełną świadomość, że jego praca pedagogiczna nie kończy się wraz dzwonkiem. Jego stosunek do ucznia powinien być zawsze pozytywny i przyjazny, on sam zaś powinien być do dyspozycji uczniów. W swoim postępowaniu ma być konsekwentny, ale nie nazbyt rygorystyczny. Powinien zawsze przestrzegać praw dziecka. Jeśli szanuje uczniów, wówczas i oni będą go szanować i darzyć szacunkiem. Życzliwy wobec starszych kolegów nie powinien dać się uwikłać w układy o charakterze personalnym, związkowym politycznym itp. Powinien dbać o swój wygląd zewnętrzny, sposób zachowania i postępowania. Pensje nauczycielskie powinny być wprost proporcjonalne do wysiłku zawodowego i ważnej roli nauczyciela w edukacji młodego pokolenia ${ }^{38}$.

Ważną cechą młodego nauczyciela powinny być kompetencje zawodowe, charakteryzujące się przede wszystkim dobrą znajomością przekazywanej uczniom wiedzy, współuczestniczenie i pomaganie podopiecznym w jej zdobywaniu. Do sformułowania wielu stanowisk i opinii należy dochodzić w dyskusji wspólnie z uczniami. Nauczyciel powinien przynajmniej w jednej dziedzinie wiedzy „błyszczeć”. Trzeba systematycznie czytać literaturę pedagogiczną i czasopisma fachowe, korzystać z podręczników metodycznych. Do każdej lekcji należy być dobrze przygotowanym i mieć napisany zwięzły konspekt. W ten sposób uniknie się improwizowania podczas przebiegu lekcji. Nie należy

\footnotetext{
37 Tamże, s. 178.

38 Tamże, s. 166, 170, 176, 178-179, 190.
} 
się bać eksperymentów. Nauczyciel powinien umiejętnie posługiwać się językami zachodnimi i współczesnym formami przekazu elektronicznego. Każdy nauczyciel, a zwłaszcza prowadzący zajęcia w klasach młodszych, powinien posiadać umiejętności artystyczne (gra na instrumencie, śpiew, taniec towarzyski), sportowe, manualne ${ }^{39}$.

Przestrzegano, aby nauczyciel nie występował nieustannie $\mathrm{w}$ roli nieomylnego mentora, który zawsze i w każdej sprawie ma rację. Taka postawa nauczyciela jest niewłaściwa i budzi zniechęcenie do niego uczniów. Do sformułowania wielu stanowisk i opinii należy dochodzić w dyskusji wspólnie z uczniami. W wypowiedziach badanych osób nieustannie pojawia się potrzeba systematycznego dokształcania i podnoszenia kwalifikacji. Wysuwano postulat, aby studia niestacjonarne dla nauczycieli były, podobnie jak dawniej, bezpłatne ${ }^{40}$.

Pewną liczbę postulatów opartych na własnych wieloletnich doświadczeniach, przemyśleniach i obserwacjach sformułowano pod adresem osób kierujących szkołami i innymi placówkami oświatowo-wychowawczymi. Przede wszystkim oczekiwano, aby w swej pracy kierowali się obiektywizmem, dawali nauczycielom określony margines samodzielności, pozwolili im działać, a nie tylko wydawać rozkazy i nakazy. Proponowano, aby dyrektorzy posiadali wiadomości z zakresu prawa administracyjnego, ekonomii, marketingu i psychologii dorosłych. Wiedza z tych dziedzin pozwoliłaby im bowiem sprawniej kierować szkołą i nauczycielami, ludźmi z reguły wrażliwymi, oczekującymi uznania, niekiedy posiadającymi kompleksy z racji dosyć częstego ich niedoceniania przez otaczające środowisko i władzę. Radzili, aby dyrektorzy byli najlepszymi nauczycielami we własnej specjalności, orientowali się w zagadnieniach metodyki nauczania poszczególnych przedmiotów, mieli ogólną wiedzę psychologiczną i pedagogiczną. Oczekiwano od nich dużej kultury osobistej, sprawiedliwego postępowania wobec podwładnych, właściwego organizowania pracy szkoły. Ponadto uważano, że nauczyciele powinni wyróżniać się gotowością do wysłuchania każdego nauczyciela, wytwarzaniem atmosfery koleżeńskości w gronie pedagogicznym, ale gdy zaistnieje potrzeba,

\footnotetext{
39 Tamże, s. 165-166, 170, 182.

40 Tamże, s. 162, 166.
} 
powinni być wymagający i udzielić upomnienia lub innej kary porządkowej. Uważano, że dyrektorzy powinni pomagać nauczycielom nawet w rozwiązywaniu trudnych spraw osobistych ${ }^{41}$. Pojawiły się też sugestie, aby dyrektorzy otoczyli szczególną troską młodych nauczycieli, pokazywali im rezultaty pracy pedagogów osiągających dobre wyniki dydaktyczno-wychowawcze, prowadzili systematyczne hospitacje lek$\mathrm{cji}^{42}$. Wszystkie działania dyrektora i rady pedagogicznej powinny być podporządkowane dobru ucznia i nauczyciela. „Osoby, które sprawują funkcje kierownicze w szkołach lub innych placówkach opiekuńczo-wychowawczych, muszą widzieć człowieka w uczniu i nauczycielu. Nie można funkcji kierowniczej sprawować zza biurka. Dyrektor musi słyszeć, jak bije serce placówki. Tym sercem jest młodzież"ł3.

Jedna z osób ankietowanych opowiedziała się za dobieraniem dyrektorów spośród nauczycieli o umiejętnościach dydaktycznych, wychowawczych i organizacyjnych. Skrytykowała system powoływania dyrektorów szkół w drodze konkursów. Stwierdziła, że konkursy są „przypadkowym wytworem ostatnich czasów”. Wyłoniony w ten sposób dyrektor nie gwarantuje należytego wypełniania zadań m.in. dlatego, że nadzór pedagogiczny nie zna jego kompetencji i nie jest w stanie nawiązać z nim właściwej współpracy ${ }^{44}$.

Uwagi i dezyderaty adresowano do osób sprawujących nadzór pedagogiczny. Oczekiwano od nich przede wszystkim obiektywnego i sprawiedliwego stosunku do nauczycieli, rzetelnych i różnorodnych form kontroli pracy dydaktyczno-wychowawczej szkół. Niektórym nauczycielom nadzór pedagogiczny kojarzy się z pełną mobilizacją szkoły, pewnym napięciem, tremą, hospitacjami, kontrolą rozkładów nauczania i różnych planów pracy. W refleksjach na ten temat nawiązywano do pozytywnych rezultatów dawnych wizytacji problemowych, frontalnych, kontroli tematycznych i lustracji. Podkreślano też rolę nauczycieli metodyków, specjalistów z danego przedmiotu,

\footnotetext{
41 Tamże, s. 161, 171, 174, 182, 190.

42 Tamże, s. 182. O pozytywnej roli dyrektora szkoły wobec początkującego nauczyciela pisze Wanda Drużka, por. W. Drużka, Nauczyciel..., s. 255.

43 Pożegnanie ze szkołą. Spojrzenie wstecz nauczyciela emeryta, s. 169.

44 Tamże, s. 180.
} 
w roztaczaniu opieki nad młodym nauczycielem. Wspominano wspólne układanie konspektów lekcji, wymianę doświadczeń w konstruowaniu pomocy dydaktycznych. Postulowano, aby w nadzorze pedagogicznym pracowali ludzie kompetentni, życzliwi nauczycielowi i odnoszący się do jego problemów ze zrozumieniem. Wyrażano przekonanie, że taka postawa przełożonych zaowocuje wzrostem ich autorytetu i zwiększy zaufanie wśród podwładnych. Podkreślano, że pracownicy nadzoru nie powinni występować, jak to się niejednokrotnie zdarzało, w roli sędziów nad nauczycielami. Powinni pamiętać, że kiedyś sami byli nauczycielami czy też dyrektorami szkół i ze zrozumieniem odnosić się do ewentualnych niedociągnięć u kontrolowanych pedagogów. Pojawiały się też nieco krytyczne opinie pod adresem aktualnej pracy nadzoru pedagogicznego. W tym kontekście formułowano postulat, aby jego pracownicy również doskonalili się zawodowo, ponieważ podlegli im nauczyciele są dobrze przygotowani do wypełniania powierzonych im zadań i z łatwością potrafią wychwycić brak kompetencji kontrolujących ich osób ${ }^{45}$. Jeden $\mathrm{z}$ ankietowanych pisze: „Utrzymuję obecnie kontakty towarzyskie z pracującymi nauczycielami i często słyszę od nich krytyczne uwagi o osobach sprawujących nadzór szkolny. Np. istnieją placówki, w których od kilku lat nie było nadzoru pedagogicznego i doradców metodycznych, mimo że mierne wyniki osiągane w tych szkołach są najlepszym dowodem o potrzebie udzielania instruktarzu przez kompetentne osoby"46.

Wielu respondentów zabrało głos na temat działalności Związku Nauczycielstwa Polskiego. Treść tych wypowiedzi była dosyć zróżnicowana, począwszy od ostrej krytyki po słowa uznania i pochwały. Przeważa pozytywna opinia o działalności ZNP. Uważano jednak, że powinien on $\mathrm{w}$ większym stopniu angażować się $\mathrm{w}$ obronę nauczycieli, lepiej reprezentować interesy swojej grupy zawodowej wobec Ministerstwa Edukacji Narodowej. Zwłaszcza w istniejącej sytuacji Związek powinien skuteczniej zabiegać o stabilność i pewność pracy nauczycieli zarówno zrzeszonych, jak i niezrzeszonych w organizacji nauczycielskiej. Pamiętając doskonale czasy pezetpeerowskie, respon-

\footnotetext{
45 Tamże, s. 18, 46, 164, 169, 171, 180-181.

46 Tamże, s. 177.
} 
denci przestrzegają działaczy związkowych przed uległością wobec jakiejkolwiek partii, wikłaniem się w sprawy polityczne i wykorzystywaniem funkcji związkowych do osiągnięcia zysków osobistych. Kilka osób podkreślało doniosłą rolę Związku w organizowaniu konferencji metodycznych. Niektórzy wyrażali żal, że ta ważna forma edukacji i integracji środowiska nauczycielskiego uległa zaniechaniu. Dosyć zaskakujące jest to, że tylko jedna respondentka wspomniała o osławionym szkoleniu ideologicznym, prowadzonym w czasach stalinowskich przez Związek. Proponowano, aby szerzej popularyzować tradycje i dorobek Związku w zakresie walki o powszechną i rzeczywistą dostępność do oświaty. Oczekiwano od działaczy tej organizacji, że będą propagować różne formy życia towarzyskiego i promować zwiększone uczestnictwo nauczycieli w korzystaniu z dóbr kultury (wyjazdy do teatru, opery itp.). Postulowano, aby ZNP w większym niż dotychczas stopniu starał się zapewnić nauczycielom godziwe warunki materialne i otaczał ich pod tym względem większą opieką ${ }^{47}$.

Kilka wypowiedzi dotyczyło sprawy reformowania systemu szkolnego po transformacji. Emeryci związkowcy prezentowali na ogół przywiązanie do ustroju szkolnego znanego im z własnej praktyki zawodowej. Do aktualnie wprowadzanych zmian mieli stosunek krytyczny. Na przykład były podinspektor szkolny i etatowy pracownik ZNP w 2000 roku radzi „połączyć wysiłki we wspólnym działaniu i skuteczniej stawiać opór wręcz szkodliwym inicjatywom MEN [...]”. Następnie mówi: „Związkowi Nauczycielstwa Polskiego życzę uporu i wytrwałości w dążeniu do poprawy stanu oświaty i sytuacji polskiego nauczyciela oraz większej skuteczności w słusznej walce z niesprawiedliwościami reform oświaty"48. Z kolei nauczycielka zaangażowana w dyskusję nad przyszłym kształtem szkolnictwa pisze: „Znowu byłam w wirze przygotowań reformy. Dyskutowaliśmy na konferencjach metodycznych, związkowych [...]. Pisaliśmy opinie, uwagi, dokształcaliśmy się i organizowaliśmy zebrania. Środowiska, w których likwidowano ośmioklasowe szkoły podstawowe, zostawiając kl. I-III, sprzeciwiały się decyzjom. Słusznie (później się to okazało) uznawa-

\footnotetext{
47 Tamże, s. 144, 162, 180-182.

48 Tamże, s. 162.
} 
no, że szkoła jako instytucja kulturotwórcza [...] powinna być w każdej wsi"49.

Niektórzy autorzy wspomnień dostrzegli w procesie wychowania po transformacji nowe zjawisko, a mianowicie wynoszenie się ponad społeczność szkolną uczniów wywodzących się z rodzin nowobogackich i pogardzanie biedniejszymi kolegami. Sytuacja ta rodziła nowe wyzwania pedagogiczne, którym nauczyciel musiał sprostać50.

Pojawiła się refleksja, że obecnie Związek jest marginalizowany i nie jest traktowany przez władzę oświatową po partnersku. Niemniej jednak jego rola w środowisku nauczycielskim jest nadal bardzo ważna, a podstawowe cele i zadania nie uległy zmianie. ZNP powinien bronić nauczycieli. Działaczom związkowym, którzy stoją na straży interesów nauczycielskich, należą się słowa uznania. Środowisko powinno ich wspierać, a gdy trzeba również i bronić przed niesłusznymi atakami oraz zarzutami z wewnątrz i zewnątrz organizacji ${ }^{51}$.

\section{UWAGI KOŃCOWE}

Podsumowując rozważania na podjęty temat, można stwierdzić, że z wypowiedzi respondentów wyłania się obraz nauczyciela pełnego poświęcenia i oddania sprawie wychowania młodego pokolenia Polaków. Wizerunek ten jest tym cenniejszy, że został oparty na relacjach powstałych w świetle własnych wspomnień i refleksji autorów. Zarządzenia i dyspozycje władz dotyczące pracy dydaktyczno-wychowawczej szkoły i nauczyciela są w tym opisie rzeczywistości edukacyjnej PRL-u na drugim, albo trzecim planie. $Z$ tego też względu również i problematyka indoktrynacji nauczycieli jest tu nieco mniej widoczna niż w wielu analizach teoretycznych. Fakt ten wyraźnie dowodzi, że wiele zaleceń o charakterze ideologiczno-politycznym nie było wśród szeregowych nauczycieli wykonywanych, zgodnie z oczekiwaniem władz partyjnych i oświatowych. Nauczyciele realizowali w swojej

\footnotetext{
49 Tamże, s. 36.

50 Tamże, s. 48.

51 Tamże, s. 180.
} 
pracy pedagogicznej wartości uniwersalne, wynikające z dorobku cywilizacji, wyniesione $\mathrm{z}$ tradycji rodzinnych i narodowych; tymi wskazaniami kierowali się $\mathrm{w}$ wychowaniu młodego pokolenia. Podobnie jak Jan Władysław Dawid sukces pedagogiczny upatrywali w miłości do uczniów. W swoich relacjach wielokrotnie podkreślali, że przede wszystkim trzeba kochać swoich podopiecznych, pracować z pełnym oddaniem, nigdy ich nie zawieść i nie liczyć na adekwatne do włożonego wysiłku wynagrodzenie.

Uzyskane przy pomocy kwestionariusza ankiety relacje i opinie ukazują też miejsce nauczyciela w niejednokrotnie dynamicznie zmieniającej się rzeczywistości, prezentują jego działalność społeczną, współpracę z rodzicami i środowiskiem. Zawierają bogactwo inicjatyw pedagogicznych i organizacyjnych, zmierzających do usprawnienia procesu edukacyjnego. Zwracają uwagę na potrzebę integracji środowiska nauczycielskiego, są pełne wartościowych wskazówek i rad adresowanych do aktualnie pracujących nauczycieli, zwłaszcza tych rozpoczynających prace w zawodzie. Opisując z perspektywy lat przebieg swojej pracy zawodowej, ukazują niełatwą drogę zawodową polskiego nauczyciela, a zarazem podkreślają jego wielkie zasługi dla wychowania wówczas młodego pokolenia, które obecnie znajduje się na etapie pracy zawodowej i wywiera istotny wpływ na rozwój społeczno-gospodarczy kraju.

\section{Summary}

The Image of a Teacher in Communist Poland in the Light of Personal Memories

This article presents the place and the role of teachers in the Polish People's Republic (PRL) from the perspective of several decades. This issue is approached, however, not in light of the preserved archival documents, produced in the centres of power, but based on accounts-memoirs of teachers and students. It is necessary to create an image of a teacher in the Polish People's Republic because of the role that they played in educating and shaping genera- 
tions of Poles who lived and worked in times of limited freedom, took part in the political upheaval and actively participated in the deep transformations that took place in the country in the last twenty-five years. It is teachers who played a special role in the implementation of educational policy in the PRL. 
